\title{
EVALUATING THE EFFECTS OF EXTENSIVE READING CIRCLES ON ESL LEARNERS' ORAL COMMUNICATIVE COMPETENCE
}

\author{
Aliyah Dato' Hj Baharuddin Marji, Shameem Rafik-Galea*, Chan Mei Yuit \\ Universiti Putra Malaysia
}

\begin{abstract}
Teaching communicative English is not easy, especially when many Malaysian learners are immersed within an environment that upholds Bahasa Malaysia as the medium of instruction in national schools. Additionally, English is now only taught as a subject and therefore, class time is limited to exposing learners to communication in English. Generally, English is an important second language in Malaysia and the government is concerned about the deteriorating level of competency among young learners as it prevents new graduates from being employed. This article represents part of a research which examined the effects of extensive reading circles (ERC) on ESL learners' oral communicative competence with two intact groups of undergraduate students who registered for the oral proficiency classes. The study employed an analytical scoring to evaluate five dimensions of oral competency during subjects' oral production interviews. Data was collected by means of pre-test and post test scores to determine the effects of ERC under two conditions scale. Results obtained from the treatment group demonstrate that subjects gained significantly on all dimensions of oral competency. Hence, the implications of these findings support the comprehensible input hypothesis and the principles underlying extensive reading and cooperative learning towards the development of oral communicative competence to ensure that learners are equipped with speaking skills pertinent for their future.
\end{abstract}

Keywords: EXTENSIVE READING, COMPREHENSIBLE INPUT HYPOTHESIS, COOPERATIVE LEARNING THEORY, READING CIRCLES, ORAL COMMUNICATIVE COMPETENCE

\section{Introduction}

The Ministry of Education Malaysia (2006) iterated that graduates need to be orally competent in English as this would assist them to convey their thoughts clearly and confidently, to demonstrate their ability to improve their thinking skills and to apply technical knowledge when providing ideas and alternative solutions. It was pointed out during the 2007 Budget speech by the Prime Minister of Malaysia, that many graduates remained unemployed due to communication skills that reflected their poor critical and analytical skills. This problem may be partly due to students entering local universities with low scores where a large number obtain Band 1 on their Malaysian University English Test (2006) or MUET, which describes students' level of English as very poor, specifically speaking skills (Nurhazlini Rahmat, Lau Sing Man, Nur Atiqah Md. Sungif \& Farah Nabillah Mior Yusup, 2014). As a result, after the 2015 Budget speech, the minimum entry point for English into many local universities is between MUET Band 2 and MUET Band 4 depending on the course students will undertake at local universities. It was observed that students who are not proficient upon entering universities would

${ }^{*}$ Corresponding author 


\section{EVALUATING THE EFFECTS OF EXTENSIVE READING CIRCLES ON ESL LEARNERS' ORAL COMMUNICATIVE COMPETENCE}

demonstrate relatively poor academic performance and produce average CGPAs after completing their tertiary education (Elder and O’Loughlin, 2003).

Studies have also observed that students lacked the opportunity to speak English in classrooms within an examination-oriented education system which focused mainly on grammar, reading and writing (Koo, 2008; Nor Hashimah Jalaludin, Norsimah Mat Awal \& Kesumawati Abu Bakar, 2008; Rahimah Haji Ahmad, 1998). Further, students were reluctant to speak the language in formal and traditional language classrooms which witnessed many language instructors relying on worksheets and workbooks (Singh, 2003). With the existence of such prevailing factors, using extensive reading circles (ERC) in classrooms may help manage L2 learning problems and improve the quality of teaching and learning a L2.

Our study employed extensive reading (ER) as a social activity to investigate the extent of subjects' incidental language acquisition. This supports Krashen's (1985) comprehensible input hypothesis where Krashen explains that using ER in the classrooms can provide meaningful, extensive and comprehensive input. He believes that learners who achieve comprehensible input in a low anxiety learning situation would then acquire the target language for L2 acquisition. Previous studies supported the use of ER in the language classrooms which impacted listening, writing, vocabulary, word recognition and grammar, reading comprehension, fluency and speed, L2 proficiency and spelling (Mason, 2011; Smith, 2010; Rodrigo, 2009; Janapoulos, 2009, 1986; Powell, 2005; Green, 2005; Horst, 2005; Sheu, 2004; Taguchi, Takayasu-Maass, \& Gorsuch, 2004). Likewise, many educators claimed that ER as an individual independent activity is pleasurable, relaxing and informal, which has contributed towards L2 learning (Nation, 2009; Mason, 2003; Day and Bamford, 2002). Some theorists have termed ER as pleasure reading (Dungworth, Grimshaw, McKnight, \& Morris, 2004), free reading (Krashen, 2004), and sustained silent reading (Garan, \& DeVoogd, 2008). In this study, ER is defined as reading extensively self-selected authentic reading materials from any interesting print or written work which will encourage students to focus on the meaning of the language.

Reading circles (RC) functions as a post-reading activity. Soliman (2012) reported that there was a lack of studies investigating ER with RC as an integrated pedagogical procedure for L2 oral development. Past studies on ER which investigated its effects on learners' language development did not however include RC (Saleem, 2010; Smith, 2010; Rodrigo, 2009; Horst, 2005; Shen, 2009). The central idea behind $\mathrm{RC}$ is for learners to interact with one another their ideas, opinions, suggestions or feelings. RC involves peer engagement and represents a task based learning approach. This is a reflection of cooperative learning first introduced by Vygotsky (1978). It was suggested by Brewer and Burgess (2005) that RC is useful since many learners depend on each other to achieve a goal or to effectively complete a task. The RC approach also encourages autonomy in oral proficiency when learners learn to speak the L2 (Khabiri \& Lavasani, 2012). Some researchers have termed RC as 'literature circles' (Bedel, 2011) and 'talking circles' (Khabiri \& Lavasani, 2012). For this study, RC is defined as a social cultural activity which allows subjects to communicate among themselves in the target language (TL) during post reading or cooperative discussions in order to help them manage, develop and improve their oral communicative competence.

Studies in the past investigated the effects of ER on language skills but did not attempt to directly study the effects of ER on oral communicative performance. Only some studies (Cho \& Krashen, 1994; Huang \& Van Naerssen, 1987; Elley \& Mangubhai, 1983, 1981) reported incidental findings on improved oral competence. A literature search revealed a dearth of studies by to name a few, Parodi (2007), Tsang (1996) and Tudor and Hafiz (1989), who investigated the effects of ER on writing improvement; however, there appears to be almost no studies that investigated the effects of ERC on oral communicative development to determine if an integrated approach could have a better impact on 


\section{EVALUATING THE EFFECTS OF EXTENSIVE READING CIRCLES ON ESL LEARNERS' ORAL COMMUNICATIVE COMPETENCE}

oral communicative competence. Likewise, recent studies used computers or identical collaborative tools to determine the effects of RC on L2 learning and acquisition (Mahmood Ahmed Hassan, Soon Fook Fong, \& Rozhan M Idrus, 2011). It was found that students using computers to self-select articles or books either increased their vocabulary size or helped skilled L2 readers improve their motivation and self-confidence (Arnold, 2009; Yamashita, 2004). Again, there was no direct study that attempted to measure oral communicative success. More importantly, past research studies which involved ER lacked control groups (Yamashita, 2008; Iwahori, 2008; Takase, 2009a; Greenberg, Rodrigo, Berry, Brinck, \& Joseph, 2006; Horst, 2005; Lai, 1993). This made it difficult to determine whether the effects from treatment using ER could be justified in such studies.

As mentioned previously, there is very little empirical evidence on the effects of ERC on speaking; however, past research on the effects of reading on writing does seem to suggest that reading can also influence the development of speaking (Cho \& Krashen, 1994; Huang \& Van Naerssen, 1987; Elley \& Mangubhai, 1983, 1981). Figure 1 demonstrates how both speakers and writers would use words to communicate. It draws on similarities between L2 speakers and writers who develop and improve speaking and writing skills respectively when exposed to ER first before RC. For example, a study by Touran (2010) revealed that ER followed by cooperative discussions during reading circles helped improve learners' writing skills.

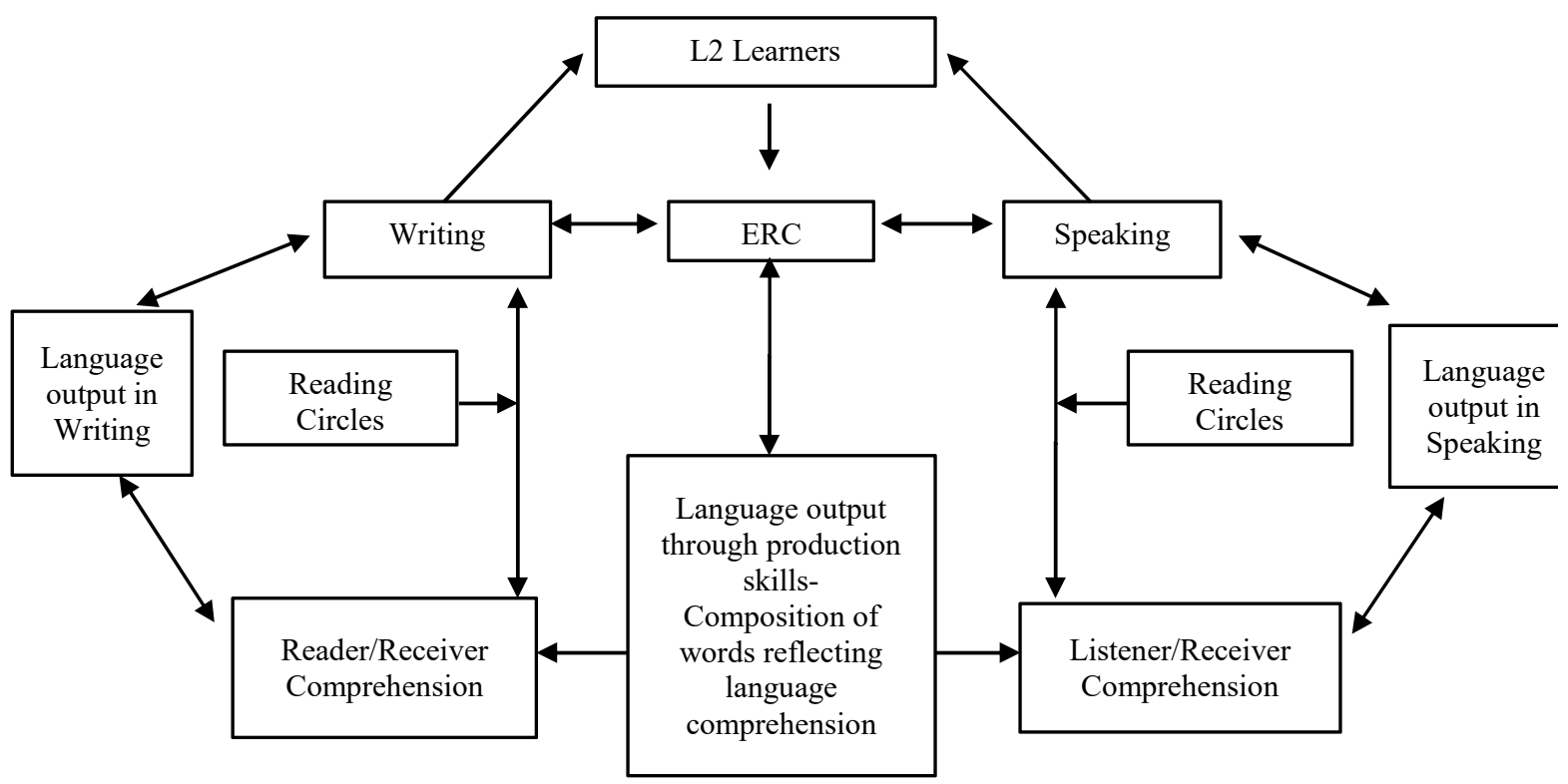

Figure 1: Similarities between Reading for Speaking and Reading for Writing

Figure 1 also explains that ER exposure helps learners to obtain newly acquired knowledge. RC is then employed as a post reading activity to allow for the exchange of ideas before the act of writing or speaking. ER followed with RC arouses speakers' and writers' interest to participate in meaningful cooperative discussions, develop linguistic schemata and increase oral and written communicative performance (Soliman, 2012). The concept of cooperative learning was introduced by Vygotsky (1978). Vygotsky explained further that learners would receive comprehensible input through ER during the inter-mental phase followed with RC for L2 output during the intra-mental phase. Thus, the 


\section{EVALUATING THE EFFECTS OF EXTENSIVE READING CIRCLES ON ESL LEARNERS' ORAL COMMUNICATIVE COMPETENCE}

goal of a speaker and a writer would be to achieve oral communicative competence or written communicative competence respectively.

The positive effects of ER on speaking are best presented by Renandya, Rajan and Jacobs (1999). Their experiment with senior Vietnamese government officials revealed that their subjects benefitted from ER towards L2 acquisition within two months. The experiment further demonstrated that subjects improved their speaking skills by retelling and answering when reading and listening to summaries and answers. Figure 2 indicates the key components of their ER program.

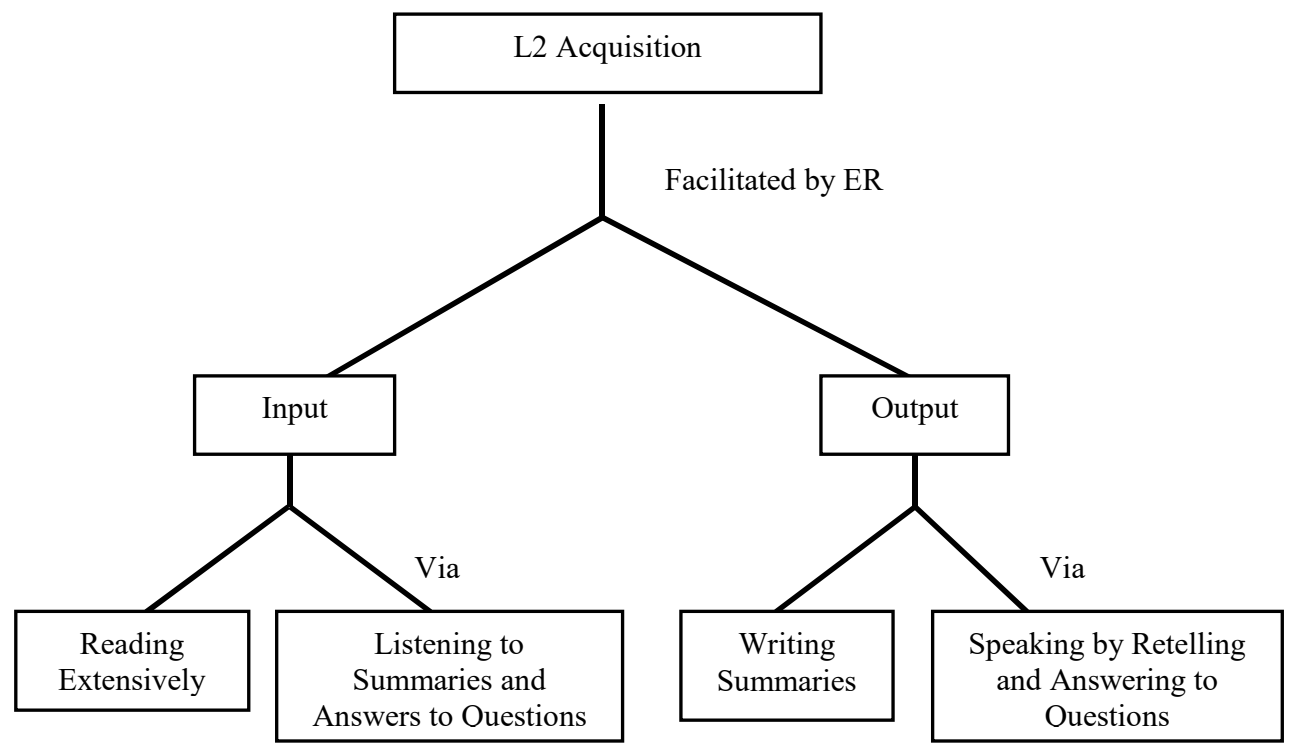

Figure 2: Input and Output Opportunities Present in an ER Program: Renandya, Rajan and Jacobs (1999, p.54)

It appears that ineffective communicative language teaching and instruction do not support language development specifically in developing speaking skills. Despite the importance of speaking, the teaching of this skill is still undervalued. . For example, language learning methods such as, the translation method was considered the most effective way to teach English (Mohd Sofi Ali, 2008; Littlewood, 2007; Nambiar, 2007). Further, the formal and traditional language classes were teacher centred with many teachers adopting the conventional grammar translation method that emphasized language production through writing (Singh, 2003). Therefore, promoting communicative competence would reflect good classroom practice. It would encourage students to express themselves and use the language appropriately for any communicative situation. This is in contrast to previous language learning methods where grammatical competence was given top priority. Hiew's (2012) study involving 46 respondents highlighted that teachers' approach to L2 teaching was non-interactive. Most respondents in this study suggested that language classrooms should be more extensive, interactive and comprehensive. 


\section{EVALUATING THE EFFECTS OF EXTENSIVE READING CIRCLES ON ESL LEARNERS' ORAL COMMUNICATIVE COMPETENCE}

\section{The Study}

The primary objective of the study was to investigate the effects of ERC on oral communicative competence. Specifically, the study employed ER with RC to investigate if this integrated task based language learning approach can help ESL undergraduate students improve their oral communicative competence and compared this with a no treatment condition. The specific objective was to determine if there is a significant difference in the effects of ERC on subjects' oral communicative competence in the pre and post-tests within the experimental and the control group and between both groups in comprehensibility, fluency of speech, vocabulary usage, grammar, syntax and pronunciation.

\section{Methodology}

The study employed a quantitative research approach. It utilized the pre-test post-test intact group quasi- experimental design for data collection to investigate the effects of an intervention using ERC on undergraduate students with poor oral communicative competence. It introduced ERC as a prerequisite class activity followed with in-class cooperative discussions to investigate if this task-based interactive language learning approach could help improve subjects' oral communicative competence and skills.

\section{Participants}

The subjects represented two intact classes randomly selected from a local institution of higher learning. Subjects underwent eleven years of L2 formal learning and were considered social users of the target language. However, their Malaysian University English Test (MUET) results revealed that they were poor users of English. Therefore, the subjects were represented by students required to attend an oral proficiency class. The subjects consisted of 43 students $(\mathrm{N}=43)$ from two different intact groups and they were assigned to the experimental and control group randomly. There were 10 males and 13 females in the experimental group in comparison with 5 males and 15 females in the control group. These subjects were Year 2 undergraduates majoring in education, arts or humanities. English majors were not included in the study. The youngest subject was 19 and the oldest was 26 years old with an average age of 21. None of the subjects had travelled to an English speaking country or had read more than two English books a year for pleasure. They seldom communicated daily in English. Table 1 presents demographic information on subjects from both groups.

Table 1: Demographic Information in Two Groups

\begin{tabular}{|c|c|c|}
\hline & $\begin{array}{c}\text { Experimental Group } \\
(\mathbf{N}=\mathbf{2 3})\end{array}$ & Control Group (N=20) \\
\hline Gender & 10 & 5 \\
$-\quad$ Male & 13 & 15 \\
$-\quad$ Female & 22 & 16 \\
\hline Ethnicity & 1 & 1 \\
$-\quad$ Malay & 0 & 3 \\
$-\quad$ Chinese & & 5 \\
$-\quad$ Others & 5 & 15 \\
\hline MUET Scores & 18 & \\
$-\quad$ Band 1 & & \\
$-\quad$ Band 2 & & \\
\hline
\end{tabular}

\section{Research Instrument}




\section{EVALUATING THE EFFECTS OF EXTENSIVE READING CIRCLES ON ESL LEARNERS' ORAL COMMUNICATIVE COMPETENCE}

The study employed several instruments and incorporated several data collection techniques for triangulation purposes to investigate the effects of ERC on subjects' oral communicative competence. However, this paper presents the findings and analysis based on the oral production interview before and after ERC intervention for both the control and experimental group.

Prior to the implementation of the study, a briefing was conducted by the one of the researchers who was also the instructor to explain the nature and purpose of the study to the subjects in the experimental group in the first phase of the study. The researchers explained that all tutorial classes would take the form of reading circles after the independent extensive reading outside of the classroom. The briefing included asking the subjects to voluntarily partake in the study, to sign a letter of consent and to receive a coded name tag before they were grouped randomly.

The second step involved the assessing and scoring of subjects in both the experimental and control group during the pre-oral production interview (pre-test). The interview adopted an interactive task type interview that required subjects from the experimental and control group to manage a conversation in a group using picture elicitation. The topics which represented non-academic everyday topics that complimented subjects' age group and interests were on Fashion Trends, Sports and Games, Health and Beauty, True Stories, World of Music, "Doctor" in the House, Travelling and Adventure and Effects of Climate Change.

Two external raters and the researcher directly assessed and rated subjects' oral communicative performance by using an analytical scoring scale that was adopted from Payne and Whitney (2002) The analytical scale provided a set of criteria for raters to assess and score five dimensions of oral communicative competence (comprehensibility, fluency of speech, vocabulary usage, grammar and syntax and pronunciation). The objective was to evaluate subjects' fluent, effective and accurate use of English.

The third step, which involved the intervention, was conducted over 14 weeks for both groups. An Extensive Reading Program Booklet listing eight non-academic reading topics was distributed to only the subjects from the experimental group. They were also encouraged to self-select reading materials according to their own interests and preference. These subjects were requested to do out of class extensive reading before attending tutorial class whereby they then shared and provided insights and information on newly acquired knowledge during reading circles in class. Subjects from the control group underwent the same routine as the experimental group. However, the exception was in the quality of their reading material. They were directed to read comprehension passages in their English workbook as assigned by their own language instructor and the researchers requested that they read these passages outside the classroom before discussing their reading topics as a group in class.

The final step involved the post oral production interviews (post-test), which were carried out in the final week of the study for both groups. The condition and process for assessing and scoring of the subjects in both the experimental and control group during the post-oral production interview (posttest) were similar to the pre-oral interview (pre-test) with the same raters using the same analytical scoring scale.

\section{Results and Discussion}

This study consisted of two groups randomly assigned to a control group and an experimental group. The total number of subjects for the study was $43(\mathrm{~N}=43)$. Twenty (20) subjects were assigned to the control group and 23 subjects to the experimental group. 


\section{EVALUATING THE EFFECTS OF EXTENSIVE READING CIRCLES ON ESL LEARNERS' ORAL COMMUNICATIVE COMPETENCE}

The Shapiro-Wilk and Kolmogorov-Smirnova tests were employed to check for normality of data obtained during the treatment. Table 2 and Table 3 present the findings of the effects of normality for both groups. The test results on normality showed that the data was distributed normally during oral production interviews. This helped to determine the effects of ERC on oral communicative competence.

Table 2: Normality Tests for Oral Communicative Competence in Pre and Post-test Control Group

\begin{tabular}{|l|l|c|c|c|c|}
\hline \multirow{2}{*}{ Proficiency } & \multirow{2}{*}{ Test } & \multicolumn{4}{|c|}{ Control } \\
\cline { 3 - 6 } & & $\begin{array}{c}\text { Kolmogorov } \\
\text { - Smirnov }\end{array}$ & $\begin{array}{c}\text { Sig } \\
.\end{array}$ & $\begin{array}{c}\text { Shapir } \\
\text { o- Wilk }\end{array}$ & Sig \\
\hline \multirow{2}{*}{ Communicative Competence } & Pre & 21 & .05 & .93 & .21 \\
\cline { 2 - 6 } & Post & .17 & .21 & .87 & .18 \\
\hline \multirow{2}{*}{ Comprehensibility } & Pre & 19 & .10 & .94 & .39 \\
\cline { 2 - 6 } & Post & .31 & .19 & .82 & .21 \\
\hline \multirow{2}{*}{ Fluency } & Pre & .20 & .09 & .87 & .08 \\
\cline { 2 - 6 } & Post & .23 & .13 & .87 & .11 \\
\hline \multirow{2}{*}{ Vocabulary } & Pre & .19 & .10 & .89 & .06 \\
\cline { 2 - 6 } & Post & .17 & .11 & .90 & .14 \\
\hline \multirow{2}{*}{ Grammar and Syntax } & Pre & .18 & .14 & .90 & .09 \\
\cline { 2 - 6 } & Post & .25 & .10 & .84 & .20 \\
\hline \multirow{2}{*}{ Pronunciation } & Pre & .21 & .09 & .93 & .34 \\
\cline { 2 - 6 } & Post & .19 & .09 & .84 & .07 \\
\hline
\end{tabular}

*. This is a lower bound of the true significance.

a. Lilliefors Significance Correction

Table 3: Normality Tests for Communicative Competence in Pre and Post-test Experimental Group

\begin{tabular}{|c|c|c|c|c|c|}
\hline \multirow[t]{2}{*}{ Proficiency } & \multirow[t]{2}{*}{ Test } & \multicolumn{4}{|c|}{ Treatment } \\
\hline & & $\begin{array}{l}\text { Kolmogorov } \\
\text { - Smirnov }\end{array}$ & Sig & $\begin{array}{c}\text { Shapiro } \\
\text { - Wilk }\end{array}$ & Sig \\
\hline \multirow{2}{*}{ Communicative Competence } & Pre & .10 & .20 & .95 & .21 \\
\hline & Post & .10 & .20 & .98 & .93 \\
\hline \multirow[b]{2}{*}{ Comprehensibility } & Pre & .14 & .15 & .94 & .17 \\
\hline & Post & .12 & .20 & .97 & .76 \\
\hline \multirow[b]{2}{*}{ Fluency } & Pre & .24 & .06 & .90 & .09 \\
\hline & Post & .12 & .20 & .96 & .60 \\
\hline \multirow{2}{*}{ Vocabulary } & Pre & .19 & .11 & .91 & .13 \\
\hline & Post & .20 & .01 & .92 & .10 \\
\hline \multirow{2}{*}{ Grammar and Syntax } & Pre & .17 & .07 & .89 & .06 \\
\hline & Post & .17 & .08 & .92 & .07 \\
\hline \multirow{2}{*}{ Pronunciation } & Pre & .17 & .10 & .89 & .08 \\
\hline & Post & .22 & .01 & .91 & .06 \\
\hline
\end{tabular}

*. This is a lower bound of the true significance.

a. Lilliefors Significance Correction 


\section{EVALUATING THE EFFECTS OF EXTENSIVE READING CIRCLES ON ESL LEARNERS' ORAL COMMUNICATIVE COMPETENCE}

The study was carried out to investigate if there was a significant difference between the pre and posttest scores within the control and experimental group for each dimension of oral communicative competence. Therefore, the study attempted to answer the question 'Does extensive reading circles have a significant effect on ESL learners' oral communicative competence in terms of comprehensibility, fluency of speech, vocabulary usage, grammar, syntax and pronunciation?' Two instruments were used to answer this question and tests were carried out to assess whether there were significant differences between the mean oral performance scores in the pre-test and post-test oral production interview before and after manipulation of the treatment for both the experimental and control groups. The tests used were the paired sample t-test and the independent t-test.

It was expected that there would be a significant difference in the effects of ERC on ESL learners' oral competency in English between pre and post-tests within both groups in terms of comprehensibility, fluency of speech, vocabulary usage, grammar and syntax and pronunciation. The rational was based on the comprehensible input theory which promotes L2 learning through an extensive reading approach (Soliman, 2012; Krashen, 2004, 1982; Cho \& Krashen, 1994; Elley, 1991).

\section{Within Group Differences}

A paired sample t- test was used to compare the means within both groups. The difference in the control group's score from the pre-test to the post-test indicates the change in the value of the dependent variable that could be expected to occur without exposure to the treatment. The difference in the experimental group's score from the pre-test to the post-test indicates the change in the value of the dependent variable that could be expected to occur with exposure to the treatment.

Table 4 shows minimal improvement for the control group. Post-test scores showed a decrease in subjects' level of oral communicative competence except for grammar/syntax and pronunciation, where the difference is significant. The reverse was found for the experimental group. Table 4 reflects a significant difference between pre-test and post-test for the experimental group in overall communicative competence but there was no significant difference between the pre-test and post-test of the control group in the overall communicative competence score. To conclude, the treatment appear to have been well received by the subjects. The findings suggests that the students realised that reading extensively was one possible approach that can help them improve their knowledge of the language before they attempt to use the language socially and interactively.

Table 4: Summary of the Paired Sample t-test within Two Groups for Each Factor of Oral Communicative Competence

\begin{tabular}{|l|c|c|c|c|c|c|c|c|}
\hline \multicolumn{1}{|c|}{ Variable } & & $\begin{array}{c}\text { Mean } \\
\text { for pre- } \\
\text { test }\end{array}$ & $\begin{array}{c}\text { Mean for } \\
\text { post-test }\end{array}$ & diff & t & df & Sig. & Decision \\
\hline Comprehensibility & C & 8.687 & 7.75 & -0.937 & -1.540 & 1 & 0.144 & Retain $\mathrm{H}_{0}$ \\
& E & 7.347 & 10.652 & 3.304 & 6.706 & 9 & $<.001$ & Reject $\mathrm{H}_{0}$ \\
& & & & & & 2 & & \\
\hline Fluency & $\mathrm{C}$ & 7.562 & 6.625 & -0.937 & -1.831 & 1 & 0.087 & Retain $\mathrm{H}_{0}$ \\
& $\mathrm{E}$ & 6.217 & 9.652 & 3.434 & 7.447 & 9 & $<.001$ & Reject $\mathrm{H}_{0}$ \\
& & & & & & 2 & & \\
\hline Vocabulary Usage & $\mathrm{C}$ & 6.875 & 6.375 & -.500 & -0.835 & 1 & 0.417 & Retain $\mathrm{H}_{0}$ \\
& $\mathrm{E}$ & 6.043 & 9.130 & 3.086 & 7.327 & 9 & $<.001$ & Reject $\mathrm{H}_{0}$ \\
\hline
\end{tabular}




\section{EVALUATING THE EFFECTS OF EXTENSIVE READING CIRCLES ON ESL LEARNERS' ORAL COMMUNICATIVE COMPETENCE}

\begin{tabular}{|l|l|l|l|l|l|l|l|l|}
\hline & & & & & & 2 & & \\
\hline Grammar and & $\mathrm{C}$ & 7.312 & 4.375 & -2.937 & -4.997 & 1 & $<.001$ & Reject $\mathrm{H}_{0}$ \\
Syntax & $\mathrm{E}$ & 5.521 & 8.130 & 2.608 & 5.079 & 5 & $<.001$ & Reject $\mathrm{H}_{0}$ \\
& & & & & & 2 & & \\
\hline Pronunciation & $\mathrm{C}$ & 6.437 & 3.875 & -2.562 & -4.965 & 1 & $<.001$ & Reject $\mathrm{H}_{0}$ \\
& $\mathrm{E}$ & 5.565 & 8.087 & 2.521 & 5.569 & 5 & $<.001$ & Reject $\mathrm{H}_{0}$ \\
& & & & & & 2 & & \\
\hline Overall Competency & $\mathrm{C}$ & 12.645 & 13.250 & -.604 & -.731 & 1 & .476 & Retain $\mathrm{H}_{0}$ \\
& $\mathrm{E}$ & 10.347 & 15.144 & 4.797 & -6.679 & 9 & .000 & Reject $\mathrm{H}_{0}$ \\
& & & & & & 2 & & \\
\hline diff = post-test - pre-test & & & & & & & & \\
\hline
\end{tabular}

The results in Table 4 illustrate that all dimensions showed a significant improvement in oral communication. This lends support to past studies and theories that reading authentic materials extensively does expose subjects to more words and does help them improve L2 skills, proficiency and competency (Smith, 2010; Nuttal, 2005; Hunt \& Beglar, 2005; Nunan, 2003; Krashen, 2004; Huang \& Van Naerssen, 1987).

The results in Table 4 suggests that subjects appear to have used ER as a cognitive language learning activity to learn the target language and to construct meaning from reading for a deeper understanding of the world (Lone, 2011; Green, 2002; Ellis, 1985). The findings further suggests that ER, as a social language learning activity, is able to expose subjects to reading when they shared their newly acquired information during reading circles. Thus, the findings propose that ER, as a social learning activity, provides a platform which arouses subjects' interest and enthusiasm to participate in meaningful communicative discourse, develop content and linguistic schemata, increase L2 learning and improve L2 literacy (Chen \& Bryer, 2012; Soliman, 2012). Therefore, it can be concluded from the post-test scores that the treatment helped subjects to achieve a better and improved level of oral communicative competence.

Assessment on subjects' communicative performance was made possible when subjects are able to carry out conversations. This is supported by Baker (2010) and Nunan (2003) who remarked that an assessment on subjects' newly acquired communicative success can be carried out when subjects participates in a discourse. Hence, subjects were assessed according to their ability to communicate orally and socially in an L2 context. Likewise, Richard (2007) commented that an assessment on subjects' communicative competence is achievable if subjects maintain comprehensible on-going communication even when they have not achieved near native proficiency, fluency and accuracy in speech. Subjects did show a capacity to improve oral communicative performance with L2 use when they were observed in class. However, they need to continue reading extensively to achieve near native fluency and accuracy.

Krashen (2004) and Jacobs and Gallo (2002) studies support the findings that this learning approach did help expose subjects to interesting and meaningful contexts, reinforce their language input through reading books and communicating with group members and improve their level of reading enthusiasm when they could share and exchange meanings in a fun interactive way. 


\section{EVALUATING THE EFFECTS OF EXTENSIVE READING CIRCLES ON ESL LEARNERS' ORAL COMMUNICATIVE COMPETENCE}

\section{Between Group Differences}

The researchers anticipated that exposure to ERC would have a significant effect on the subjects' oral communicative competence between both groups for comprehensibility, fluency of speech, vocabulary usage, grammar, syntax and pronunciation.

An independent sample t-test was employed to compare the mean difference between both groups. The difference between the change in both the experimental group and the control group would demonstrate the amount of change in the value of the dependent variable. This can be attributed to the influence of the treatment. One assumption to consider under this parametric test is the assumption of equal variance among different samples. To check the differences between both groups in communicative competency, an independent t-test was conducted between the pre-test scores of both groups prior to the intervention. Table 5 shows the results of the pre-test t-test which indicates no significant differences in overall communicative competence and in all five dimensions of oral communicative competence.

Table 5: Independent Sample t-test between Two Groups for Each Factor of Oral Communicative Competence

\begin{tabular}{|c|c|c|c|c|c|c|c|}
\hline \multirow[b]{2}{*}{ Comprehensibility } & \multicolumn{2}{|c|}{$\begin{array}{c}\text { Levene's Test for } \\
\text { Equality of Variances }\end{array}$} & \multicolumn{4}{|c|}{ t-test for Equality of Means } & \multirow[t]{2}{*}{ Decision } \\
\hline & $\mathrm{F}$ & Sig. & $\mathrm{t}$ & $\mathrm{df}$ & $\begin{array}{l}\text { Sig. (2- } \\
\text { tailed) }\end{array}$ & $\begin{array}{c}\text { Mean } \\
\text { Diff }\end{array}$ & \\
\hline Equal variances assumed & .309 & .582 & 5.446 & 41 & .000 & 4.24185 & $\begin{array}{c}\text { Reject research } \\
\text { hypothesis }\end{array}$ \\
\hline $\begin{array}{l}\text { Equal variances not } \\
\text { assumed }\end{array}$ & & & 5.416 & 31.792 & .000 & 4.24185 & \\
\hline \multirow[b]{2}{*}{ Fluency } & \multicolumn{2}{|c|}{$\begin{array}{c}\text { Levene's Test for } \\
\text { Equality of Variances }\end{array}$} & \multicolumn{4}{|c|}{ t-test for Equality of Means } & Decision \\
\hline & $\mathrm{F}$ & Sig. & $\mathrm{t}$ & df & $\begin{array}{l}\begin{array}{l}\text { Sig. (2- } \\
\text { tailed) }\end{array} \\
\end{array}$ & $\begin{array}{c}\text { Mean } \\
\text { Diff } \\
\end{array}$ & \\
\hline Equal variances assumed & .693 & .410 & 6.255 & 41 & .000 & 4.37228 & $\begin{array}{c}\text { Reject research } \\
\text { hypothesis }\end{array}$ \\
\hline $\begin{array}{l}\text { Equal variances not } \\
\text { assumed }\end{array}$ & & & 6.344 & 33.968 & .000 & 4.37228 & \\
\hline \multirow[b]{2}{*}{ Vocabulary Usage } & \multicolumn{2}{|c|}{$\begin{array}{c}\text { Levene's Test for } \\
\text { Equality of Variances }\end{array}$} & \multicolumn{4}{|c|}{ t-test for Equality of Means } & Decision \\
\hline & $\mathrm{F}$ & Sig. & $\mathrm{t}$ & df & $\begin{array}{l}\text { Sig. }(2- \\
\text { tailed) }\end{array}$ & $\begin{array}{c}\text { Mean } \\
\text { Diff }\end{array}$ & \\
\hline Equal variances assumed & 1.054 & .311 & 5.054 & 41 & .000 & 3.58696 & $\begin{array}{c}\text { Reject research } \\
\text { hypothesis }\end{array}$ \\
\hline $\begin{array}{l}\text { Equal variances not } \\
\text { assumed }\end{array}$ & & & 4.900 & 28.735 & .000 & 3.58696 & \\
\hline \multirow[b]{2}{*}{ Grammar and Syntax } & \multicolumn{2}{|c|}{$\begin{array}{c}\text { Levene's Test for } \\
\text { Equality of Variances }\end{array}$} & \multicolumn{4}{|c|}{ t-test for Equality of Means } & Decision \\
\hline & $\mathrm{F}$ & Sig. & $\mathrm{t}$ & df & $\begin{array}{l}\text { Sig. }(2- \\
\text { tailed) }\end{array}$ & $\begin{array}{c}\text { Mean } \\
\text { Diff }\end{array}$ & \\
\hline Equal variances assumed & .876 & .355 & 7.044 & 41 & .000 & 5.54620 & $\begin{array}{c}\text { Reject research } \\
\text { hypothesis }\end{array}$ \\
\hline $\begin{array}{l}\text { Equal variances not } \\
\text { assumed }\end{array}$ & & & 7.105 & 33.379 & .000 & 5.54620 & \\
\hline
\end{tabular}




\section{EVALUATING THE EFFECTS OF EXTENSIVE READING CIRCLES ON ESL LEARNERS' ORAL COMMUNICATIVE COMPETENCE}

\begin{tabular}{|c|c|c|c|c|c|c|c|}
\hline \multirow[b]{2}{*}{ Pronunciation } & \multicolumn{2}{|c|}{$\begin{array}{c}\text { Levene's Test for } \\
\text { Equality of Variances }\end{array}$} & \multicolumn{4}{|c|}{ t-test for Equality of Means } & \multirow[t]{2}{*}{ Decision } \\
\hline & $\mathrm{F}$ & Sig. & $\mathrm{t}$ & $\mathrm{df}$ & $\begin{array}{l}\text { Sig. (2- } \\
\text { tailed) }\end{array}$ & $\begin{array}{c}\text { Mean } \\
\text { Diff }\end{array}$ & \\
\hline Equal variances assumed & .662 & .421 & 7.336 & 41 & .000 & 5.08424 & $\begin{array}{c}\text { Reject research } \\
\text { hypothesis }\end{array}$ \\
\hline \begin{tabular}{|l|}
$\begin{array}{l}\text { Equal variances not } \\
\text { assumed }\end{array}$ \\
\end{tabular} & & & 7.405 & 33.460 & .000 & 5.08424 & \\
\hline \multirow{2}{*}{$\begin{array}{l}\text { Overall Competency } \\
\text { Score }\end{array}$} & \multicolumn{2}{|c|}{$\begin{array}{c}\text { Levene's Test for } \\
\text { Equality of Variances }\end{array}$} & \multicolumn{5}{|c|}{ t-test for Equality of Means } \\
\hline & $\mathrm{F}$ & Sig. & $\mathrm{t}$ & df & $\begin{array}{c}\text { Sig. } \\
(2- \\
\text { tailed) }\end{array}$ & $\begin{array}{l}\text { Mean } \\
\text { Diff. }\end{array}$ & $\begin{array}{l}\text { Std. Error } \\
\text { Diff }\end{array}$ \\
\hline $\begin{array}{l}\text { Equal Variances } \\
\text { Assumed } \\
\text { Equal Variances not } \\
\text { Assumed }\end{array}$ & .990 & .326 & -2.503 & 35.493 & 0.20 & $\begin{array}{l}-1.89493 \\
-1.89493\end{array}$ & .78060 \\
\hline
\end{tabular}

Mean Difference = treatment mean - control mean

The equality of variances is a necessary assumption when doing t-tests; therefore, Levene's test for equality of variances was selected to check whether equal variance assumed was violated. The test for equality was not significant when $p$-value is above significant alpha value of .05 for each dimension of oral competency. The assumption of equal variance from different samples was therefore not violated. The result for the independent sample t-test is read according to results shown in the 'equal variances assumed' rows. Table 5 indicates that all t-tests for equality of means show highly significant results with $p$-value $<.001$. We can conclude then that the study did meet its objective. The mean difference for the two group's ranges between 3.586 and 5.546 from an original score scale of 0 to 15 . There is a significant difference between the post-test experimental group $(\mathrm{M}=15.144, \mathrm{SD}=2.550)$ and the posttest control group $(\mathrm{M}=13.250, \mathrm{SD}=2.155)$ for communicative competence and in all five dimensions of oral communicative competency $(41)=-2.428, p$-value $<.020$.

The results in Table 5 also imply that social learning does help promote social constructivism (Vygotsky, 1978). As observed in class, subjects increased their usage of English when they became active learners. The treatment allowed subjects to develop their thinking and reasoning skills, to enhance meanings with opinions, ideas and suggestions when negotiating, arguing or agreeing, to improve knowledge of language among themselves in grammar, pronunciation and vocabulary as suggested by Matsumura, Slater and Crosson (2008), Reznitskaya, Anderson and Kuo (2007), Dyson (2004) and Nystrand (1996).

In brief, the treatment, which provided comprehensive language input through ER, has encouraged subjects to increase their usage of L2 through RC. This has significantly improved learners' level of oral communicative competence specifically, their comprehensibility, fluency of speech, vocabulary usage, grammar and syntax including pronunciation.

\section{Conclusion}

Developing L2 is often seen as a continuous and dynamic process. Obtaining continuous input and having the opportunity to use the language helps L2 learners learn and master a L2. The study was conducted to investigate if ERC can be considered as an in-class social cultural activity towards improving and developing oral communicative competence. Consequently, it adopted a quasi- 


\section{EVALUATING THE EFFECTS OF EXTENSIVE READING CIRCLES ON ESL LEARNERS' ORAL COMMUNICATIVE COMPETENCE}

experimental research design with a pre-test post-test control group to investigate the effects of ERC within and between groups before and after intervention.

One of the goals for this study is to help subjects develop and improve their oral communicative performance and competence. The results demonstrated that ERC as a language learning activity could be assimilated into the English language curriculum in the future. The results further demonstrated that subjects can improve oral communicative competence through the intervention of the treatment. This is in contrast to the conventional language teaching method where authentic reading materials are not used in class.

The use of ERC allowed subjects to use English willingly when they discovered their ability and skills to orally construction newly acquired knowledge. As suggested by Bamford and Day (2004) and Daniels (2002), this activity does allow L2 learners to explore common interests and to share opinions, ideas, suggestions and understanding. As a result, subjects managed to create and develop social relationships in a fun and interactive way when ERC encouraged subjects to generate and articulate ideas, opinions and solutions clearly, freely and unselfconsciously in L2 as suggested by Furr (2004) and Doolittle and Hicks (2003).

To conclude, ERC can help subjects progress towards learning the language in context before using the language socially and interactively in comparison with subjects who learned the language individually for oral communicative competence. As suggested by Gee (1999) and Cunningham (2009), L2 learners would be more competent after reading extensively. In other words, they could be more competent if they enjoy reading and have the urge to want to read more. Further, reading encourages subjects to be conscious of words in order to build vocabulary (Fisher et al., 2009; Scott \& Nagy, 2004). It can also be concluded that ERC allows subjects to learn not only from the reading texts but also from and with one another (Vacca, Vacca, \& Mraz, 2011; Bromley, 2008; Routman, 2005, 2003).

Hence, this study does support and recommend the future use of ERC in all language classrooms. It would be ideal if the Malaysian government schools incorporate ERC into the English language curriculum as a possible approach to develop L2 learners' speaking skills from the primary level to assist the generally poor or weak students. Depending on the needs and requirements of students to develop their language, fluency, accuracy and proficiency for communicative competence, this approach can be manipulated accordingly.

\section{References}

Arnold, N. (2009). Online extensive reading for advanced foreign language learners: An evaluation study, ( $7^{\text {th }}$ ed.). Foreign Language Annals, 42(2): 340-366.

Baker, T.J. (2010). Oral fluency and extensive reading activities. (Online) Retrieved, 2 April, 2011 from http://ihjournal.com/oral-fluency-and-extensive-reading-activities.

Bamford, J., \& Day, R.R. (Eds.) (2004). Extensive reading activities for teaching language. Cambridge, UK; New York: Cambridge University Press.

Bedel, O. (2011). Literature circles in EFL: How they stimulate the social interaction". ELT Digest. (Online) Retrieved 19 March, 2015 from http://eltdigest.com/ literature circles/?pageid=7 


\section{EVALUATING THE EFFECTS OF EXTENSIVE READING CIRCLES ON ESL LEARNERS' ORAL COMMUNICATIVE COMPETENCE}

Brewer, E.W., \& Burgess, D.N. (2005). Professor's role in motivating students to attend class. Journal of Industrial Teacher Education, 42(23): 23-47.

Bromley, K. (2008). Actively engaging middle school students with words. In K.A. Hinchman and H.K. Sheridan-Thomas (Eds.), Best practices in adolescent literacy instruction (pp. 99-113). New York, NY: Guilford Press.

Chen, B., \& Bryer, T. (2012). Investigating instructional strategies for using social media in formal and informal learning. International Review of Research in Open and Distance Learning, 13(1): 87104.

Cho, K.S., \& Krashen, S.D. (1994). Acquisition of vocabulary from the Sweet Valley Kids Series: Adult ESL acquisition. Journal of Reading, 37: 662-667.

Cunningham, P. (2009). What really matters in vocabulary: Research-based practice across the curriculum? New York, NY: Pearson.

Daniels, H. (2002). Literature circles: Voice and choice in book clubs and reading groups. York, ME: Stenhouse Publishers.

Day, R.R., \& Bamford, J. (2002). Top ten principles for teaching extensive reading. Reading in a Foreign Language, 14(2): 136-141.

Doolittle, P.E., \& Hicks, D. (2003). Constructivism as a theoretical foundation for the use of technology in social studies. Theory and Research in Social Education, 31(1): 72-104.

Dungworth, N., Grimshaw, S., McKnight, C., \& Morris, A. (2004). Reading for pleasure: A summary of the findings from a survey of the reading habits of year 5 pupils. New Review of Children's Literature and Librarianship, 10: 169-188.

Dyson, A.H. (2004). Writing and the sea of voices: Oral language in, around, and about writing. In R.B. Ruddell \& N.J. Unrau (Eds.), Theoretical models and processes of reading (pp. 146-162). Newark, DE: International Reading Association.

Elder, C., \& O'Loughlin, K. (2003). Investigating the relationship between intensive English language study and band score gain on IELTS. IELTS Research Reports, 4.

Elley, W.B., \& Mangubhai, F. (1983). The impact of reading on second language learning. Reading Research Quarterly, 19: 53-67.

Elley, W.B., \& Mangubhai, F. (1981). The impact of a book flood in Fiji primary schools. Wellington: New Zealand Council for Educational Research and Institute of Education, the University of the South Pacific.

Elley, W.B. (1991). Acquiring literacy in a second language: The effect of book-based programs. Language Learning, 41(3): 375-411.

Ellis, R. (1985). Teacher-pupil interaction in second language development. In S. Gass \& C. Madden (Eds.), Input in second language acquisition (pp. 69-88). Rowley, MA: Newbury House. 


\section{EVALUATING THE EFFECTS OF EXTENSIVE READING CIRCLES ON ESL LEARNERS' ORAL COMMUNICATIVE COMPETENCE}

Fisher, D., \& Frey, N. (2009). Background knowledge: The missing piece of the comprehension puzzle. Portsmouth, NH: Heinemann.

Furr, M. (2004). How and why to use EFL literature circles. (Online) Retrieved 17 October, 2013 from http://www.eflliteraturecircles.com.

Garan, E.M. \& DeVoogd, G. (2008). The benefits of sustained silent reading: Scientific research and common sense converge. The Reading Teacher, 62(4): 336-344.

Gee, R. W. (1999). Encouraging ESL students to read. TESOL Journal, 8(1): 3-7.

Green, C. (2005). Integrating extensive reading in the task-based curriculum. ELT Journal, 59(4): 306311.

Greenburg, D., Rodrigo, V., Berry, A., Brinck, T., \& Joseph, H. (2006). Implementation of an extensive reading program with adult learners. Adult Basic Education, 16(20): 81-97

Green, P. (2002). Teachers intervention in children's reading. Journal of Child Hood Education, 46(3): 147-149.

Hiew, W. (2012). English language teaching and learning issues in Malaysia: Learners' perceptions via facebook dialogue journal. Journal of Arts, Science and Communication, 3(1).

Horst, M. (2005). Learning L2 vocabulary through extensive reading: A measurement study. Canadian Modern Language Review, 61(3): 355-382.

Huang, X., \& Van Naerssen, M. (1987). Learning strategies for oral communication. Applied Linguistics, 8(3): 287-307.

Hunt, A., \& Beglar, D. (2005). A framework for developing EFL reading vocabulary. Reading in a Foreign Language, 17(1): 23-59. (Online) Retrieved 24 March, 2012 from http://nflrc.hawaii.edu/rfl/April2005/hunt/hunt.html.

Iwahori, Y. (2008). Developing reading fluency: A study of extensive reading in EFL. Reading in a Foreign Language, 20: 70-91.

Jacobs, G., \& Gallo, P. (2002). Reading alone together: Enhancing extensive reading via studentstudent cooperation. Reading Online, 5(6). (Online) Retrieved, 23 November, 2013 from http://www.readingonline.org/articles/art index.asp?HREF=jacobs/index.html.

Janopoulos, M. (2009). Pleasure reading and writing in a second language: (How) can we make the connection? In A. Cirocki (ed.), Extensive reading in English language teaching (pp. 429-438). Lincom Europa.

Janopoulos, M. (1986). The relationship of pleasure reading and second language writing proficiency. TESOL Quarterly, 20(4): 763-768.

Khabiri, M., \& Lavasani, M. (2012). A collaborative approach to autonomy: Does it improve EFL learners' oral proficiency? World Applied Sciences Journal, 20 (9): 1293-1299. (Online) Retrieved 12 January, 2015 from http://www.idosi.org/wasj/wasj20 (9)12/17.pdf. 


\section{EVALUATING THE EFFECTS OF EXTENSIVE READING CIRCLES ON ESL LEARNERS' ORAL COMMUNICATIVE COMPETENCE}

Koo Yew Lie. (2008). Language, culture and literacy: Meaning-making in global contexts. Bangi: Penerbit Universiti Kebangsaan Malaysia.

Krashen, S.D. (2004). The power of reading. Portsmouth, NH: Heinemann Publishing Company.

Krashen, S.D. (1982). Principles and practice in second language acquisition. Pergamon.

Lai Fung-Kuen (1993). The effect of a summer reading course on reading and writing skills. System, 21: $87-100$.

Lone, F.A. (2011).Reading habits of rural and urban college students in the 21st Century. Library Philosophy and Practice E- Journal (pp. 1-9). (Online) Retrieved 4 December, 2014 from http://digitalcommons.unl.edu/libphilprac/586.

Matsumura, L.C., Slater, S.C., \& Crosson, A. (2008). Classroom climate, rigorous instruction and curriculum, and students' interactions in urban middle schools. The Elementary School Journal, 108(4): 294-312.

Mahmood Ahmed Hassan, Soon Fook Fong, \& Rozhan M Idrus. (2011). Impact of e-cooperative learning modules on interpersonal communication skills. In A. Zaharim et al. (eds.), Recent researches in education (pp. 25-30). Penang, Malaysia: WSEAS.

Mason, B. (2003). A study of extensive reading and the development of grammatical accuracy by Japanese university students learning English. (Ph.D. Dissertation), Temple University, Osaka, Japan.

Mason, B. (2011). Impressive gains on the TOEIC after one year of comprehensible input, with no output or grammar study. International Journal of Foreign Language Teaching, 7: 1-5.

Ministry of Higher Education Malaysia (2006). Development of soft skills for Institutions of Higher Learning. Universiti Putra Malaysia.

MUET (2006). Syllabus. Handbook of Malaysian University English Test. Selangor, Malaysia: Majlis Peperiksaan Malaysia.

Nation, I.S.P. (2009). Teaching ESL/EFL reading and writing. New York: Routledge

Nor Hashimah Jalaludin, Norsimah Mat Awal \& Kesumawati Abu Bakar. (2008). The mastery of English language among lower secondary school students in Malaysia: A linguistic analysis. European Journal of Social Sciences, 7 (2): 106-119.

Nunan, D. (2003). Practical English language teaching. NY: McGraw-Hill

Nurhazlini Rahmat, Lau Sing Min, Nur Atiqah Md. Sungif \& Farah Nabillah Mior Yusup.(2014). English language proficiency tests and academic achievement: A study on the Malaysian University English Test as a predictor of technical program undergraduates' academic achievement. (Online) Retrieved $10 \quad$ November, 2014 from www.journals.aiac.org.au/index.php/alls/article/view/630.

Nuttal, C. (2005). Teaching reading skills in a foreign language. Oxford, UK: MacMillan Education. 


\section{EVALUATING THE EFFECTS OF EXTENSIVE READING CIRCLES ON ESL LEARNERS' ORAL COMMUNICATIVE COMPETENCE}

Nystrand, M. (1996). Opening dialogue: Understanding the dynamics of language and learning in the English classroom. New York: Teachers College Press.

Parodi, G. (2007). Reading-writing connections: Discourse-oriented research. Reading and Writing, 20: $225-250$

Powell, S. (2005). Extensive reading and its role in Japanese high schools. The Reading Matrix, 5: 2842.

Rahimah Haji Ahmad (1998). Educational development and reformation in Malaysia. Past, present and future. Journal of Educational Administration, 36(5): 462-475. (Online) retrieved 13 September, 2013 from http://dx.doi.org/10.1108/09578239810238456

Renandya, W.A., Rajan, S., \& Jacobs, G.M. (1999). Extensive reading with adult learners of English as a second language. RELC Journal, 30(1): 39-61.

Reznitskaya, A., Anderson, R.C., \& Kuo, L.J. (2007). Teaching and learning argumentation. Elementary School Journal, 107: 449-472.

Richards, J.C. (2007). Communicative language teaching today. Cambridge: Cambridge University Press. 13

Rodrigo, V. (2009). Vocabulary size and reading habit in native and non-native speakers of Spanish. Hispania, 92(3): 580-592.

Routman, R. (2003). Reading essentials: The specifics you need to teach reading well. Ports-mouth, NH: Heinemann.

Routman, R. (2005). Writing essentials: Raising expectations and results while simplifying teaching. Portsmouth, NH: Heinemann.

Saleem, B.A.A. (2010). Impact of extensive reading on literacy perceptions and on EFL writing quality of English major students at the Islamic University of Gaza. (MA Thesis). The Islamic University, Gaza.

Scott, J.A., \& Nagy, W.E. (2004). Developing word consciousness. In J.F. Baumann \& E.J. Kame'enui (Eds.), Vocabulary instruction: Research to practice (pp. 201-217). New York, NY: Guilford.

Shen, M. (2009). Reading-writing connection for EFL college learners' literacy development. Asian EFL Journal, 11(1): 87-106.

Sheu, P.H. (2004). Extensive reading as a breakthrough in a traditional EFL curriculum: Experimental research in Junior High Schools in Taiwan. (PhD Thesis), University of Warwick, England. Retrieved 12 April 2013 from http://core.ac.uk/display/47137.

Singh, M.K. (2003). The use of cooperative learning method in the teaching and learning process in reading comprehension to increase learner achievement at tertiary level. In A. Pandian, G. Chakravarthy, and S. Che Lah (eds.), English language teaching and literacy: Research and reflections (pp. 110-119). Serdang: University Putra Malaysia Press. 


\section{EVALUATING THE EFFECTS OF EXTENSIVE READING CIRCLES ON ESL LEARNERS' ORAL COMMUNICATIVE COMPETENCE}

Smith, K. (2010). Integrating one hour of in-school weekly SSR: Effects on proficiency and spelling. International Journal of Foreign Language Teaching, 7(1):1-7.

Soliman, N.A. (2012). Integrating extensive reading and reading circles in ESL. International Journal of Global Education, 1(1): 26-34.

Taguchi, E., Takayasu-Maass, M., \& Gorsuch, G.J. (2004). Developing reading fluency in EFL: How assisted repeated reading and extensive reading affect fluency development. Reading in a Foreign Language, 16: 1-23.

Takase, A. (2009a). The effects of different types of extensive reading materials on reading amount, attitude and motivation. In A. Cirocki (ed.), Extensive reading in English language teaching (pp. 451-465). Munich, Germany: Lincom.

The Economic Planning Unit, Prime Minister's Department (2006). Ninth Malaysia Plan, 2006-2010. Putra Jaya.

Touran, A. (2010). Effect of cooperative directed reading on the writing performance of ESL undergraduate students. (Ph.D Thesis). Universiti Putra Malaysia.

Tsang, W. (1996). Comparing the effects of reading and writing on writing performance. Applied Linguistics, 17(2): 210-233.

Tudor, I., \& Hafiz, F. (1989). Extensive reading as a means of input to L2 learning. Journal of Research in Reading, 12: 164-178.

Vacca, R.T., Vacca, J.A.L., \& Mraz, M. (2011). Content area reading: Literacy and learning across the curriculum (10th ed.). Boston, MA: Pearson.

Vygotsky, L.S. (1978). Mind in society: The development of higher psychological processes, James V. Wertsch (ed.).Cambridge, MA: Harvard University Press.

Yamashita, J. (2004). Reading attitudes in L1 and L2, and their influence on L2 extensive reading. Reading in a Foreign Language, 16(1), 1-19.

Yamashita, J. (2008). Extensive reading and development of different aspects of L2 proficiency. System, 36(4): 661-672.

\section{Biodata:}

Aliyah Dato' Hj Baharuddin Marji completed her Bachelors and Masters' degree from the University of Illinois, USA, She joined a commercial bank and was assigned to train staff in areas pertaining to soft skills. With 25 years of experience, she has been conducting programs around Malaysia before she decided to pursue her Ph.D. with Universiti Putra Malaysia. Address of correspondence: Department of English, Faculty of Modern Languages and Communication, Universiti Putra Malaysia, 43400, Serdang, Selangor, Malaysia. Email: aliyah bm@yahoo.com 


\section{EVALUATING THE EFFECTS OF EXTENSIVE READING CIRCLES ON ESL LEARNERS' ORAL COMMUNICATIVE COMPETENCE}

Chan Mei Yuit is a senior lecturer in the department of English, Faculty of Modern Languages and Communication. She specialises in Applied Linguistics, Discourse and Communication Studies, Language Learning and Acquisition and Language for Specific Purposes. Her areas of research are Institutional and professional Discourse Practices, Language and Communication in Health and Medical Contexts, Discourse of Indigenous Communities and Language and Cognition. Address of correspondence: Department of English, Faculty of Modern Languages and Communication, Universiti Putra Malaysia, 43400, Serdang, Selangor, Malaysia. Email: cmy@upm.edu.my

Shameem Rafik-Galea is an Associate Professor in the department of English, Faculty of Modern Languages and Communication. She holds a PhD in Applied Linguistics and TESOL from the University of Leicester, UK. She has researched widely and has presented papers in the area of English language teaching and teacher education, languages for specific purposes and language use in the workplace. Her main research interests is in the area of Languages for Specific Purposes, particularly in the context of language use in workplace settings including organisational and business communication and healthcare settings. In addition, she also researches in the areas of discourse studies and second language teaching and learning. Address of correspondence: Department of English, Faculty of Modern Languages and Communication, Universiti Putra Malaysia, 43400, Serdang, Selangor, Malaysia. Email: shameemgalea@gmail.com 